Open Access

\title{
The impact of Internet finance on commercial banks' risk taking: evidence from China
}

Pin Guo and Yue Shen

\author{
* Correspondence: \\ guopin198961@163.com \\ School of Economics and Finance, \\ Xi'an Jiaotong University, Yan Ta \\ West Road N0. 74, 710061 Xi'an, \\ Shaanxi, People's Republic of China
}

\begin{abstract}
Background: Internet finance has grown rapidly in China over the past years. Through introducing internet finance's "reducing management cost" and "raising capital cost" effects into bank risk-taking model, this paper systematically investigates the dynamic and heterogeneous influence of internet finance on China commercial banks' risk-taking.

Methods: Using internet finance index based on "text mining" and data of 36 commercial banks from 2003 to 2013, we makes an SYS-GMM test.

Results: The results show, firstly, the impact of internet finance on China commercial banks' risk-taking is a " $U$ " trend. The initial development of internet finance can help commercial banks to reduce management cost and risk-taking, but then internet finance will raise capital cost, and turn to exacerbate banks' risk-taking. Secondly, the response of China commercial banks' risk-taking is heterogeneous. Large commercial banks' response is slow, while small and medium banks' response is relatively sensitive.

Conclusions: The conclusion showed the complexity of the implication mechanism and functional process of how internet finance affected China commercial banks' risk-taking.

Keywords: Internet finance, Commercial bank risk taking, System GMM estimation JEL classification: E44, G21, G29
\end{abstract}

\section{Background}

From simple imitation a decade ago to today's proactive innovation, China's Internet finance has demonstrated its role as the driving force, which should not be neglected. Over the past 2 years, in particular, Internet finance has emerged as the "blue ocean" enjoying tremendous development where numerous virtual and real enterprises vied to swim into that area. On July 18, 2015, the Guideline on Promoting the Healthy Development of Internet Finance (hereinafter referred to as the Guideline) was jointly issued by 10 ministries and departments including the People's Bank of China. The Guideline indicated that the deep integration of Internet and finance was a prevailing trend, which would exert a profound influence on financial organization, financial products and financial service, but Internet finance had not changed the features of financial risks such as secret, contagious, wide-spread, and sudden. As a new type of finance business, Internet finance has broken the traditional boundary, propelled the process of financial disintermediation, and brought an overall impact on

(c) The Author(s). 2016 Open Access This article is distributed under the terms of the Creative Commons Attribution 4.0 International License (http://creativecommons.org/licenses/by/4.0/), which permits unrestricted use, distribution, and reproduction in any medium, provided you give appropriate credit to the original author(s) and the source, provide a link to the Creative Commons license, and indicate if changes were made. 
commercial banking. Against this background, the ever increasing importance has been attached to the discussion on the relation between Internet finance and commercial banks.

Based on the documents we grasped, scholars differed in their opinions toward the definition of Internet finance. Shahrokhi (2008) maintained that Internet finance was a third financing model which was different from either the indirect financing of commercial bank or the direct financing in capital market. Instead, Zhiwu (2014) pointed out that Internet finance was an extension and upgrading of traditional financial service and was regulatory arbitrage taking advantage of the defect of China' financial system, instead of the so-called new finance. But the unveiling of this Guideline ended the debate. It clearly showed that Internet finance was a new model of financing sector where traditional financial institutions and Internet corporations conducted accommodation of funds, payment, investment, and information intermediary service by way of Internet technology and information communication technology.

The integration relation between Internet finance and traditional finance has been highly focused. From the perspective of financial function, Syed and Nida (2013) considered that Internet finance and commercial bank enjoyed their advantages respectively regarding financial functions, and both of them should be guided to compete and cooperate so as to promote the development and innovation of finance. From the perspective of financial repression, Guoqiang and Pengfei (2014) stressed that Internet finance was produced by interest rate control, and its rapid development would facilitate the process of the marketization of interest rate and raise the financing cost, which added the risk facing commercial banks. From the perspective of financial service, Zhilai (2015) indicated that Internet finance exerted great impact on commercial bank including its debt, asset, and intermediary service and would create an atmosphere with commercial bank featuring rapid diversion of debt and dislocation competition among assets, as well as rivalry against Internet finance in payment. In addition, viewed from the perspective of technology spillover, Yue and Pin (2015) analyzed how the promotion mechanism caused by Internet finance function on total factor productivity of commercial bank.

It has been another focus of spill-over effect and risk management targeting Internet finance. Xiaoqiu (2015) pointed out that Internet finance reduced transaction cost, facilitated market competition, enriched the finance implication, and pushed forward the financial reform. However, some risks also emerged ranging from dependence on technology and absence of trust to failure in business due to the lack of rules and regulations. Thus, it is imperative to conduct supervision and management over Internet finance and adhere to the principles of "lawful, moderate, classified, coordinated and innovative supervision and management," so as to promote its sustainable development (Haier and Wuguang 2015).

Undoubtedly, the above materials have made valuable contributions to the understanding of Internet finance. But the discussion on Internet finance and commercial banks' risk taking is rare. Considering this, theoretical model was firstly adopted in this article to illustrate the influence mechanism resulted by Internet finance for the risk taking of commercial bank and then the micro-panel data of China's 36 commercial banks from 2003 to 2013 were used to conduct empirical test. Research showed that from the perspective of dynamic progress, Internet finance had a U-shaped (downward then upward) trend impact on risk taking of commercial bank. In other words, at the beginning, Internet finance benefited commercial bank for it reduced management cost and risk taking, but then, it would raise the capital cost and increase the risk taking of 
commercial bank. From the angle of horizontal comparison, the risk taking of different types of commercial banks was heterogeneous in the reaction to Internet finance. Compared to small-and-medium commercial banks, large ones were slow to respond.

The contributions of this article mainly include the following: (1) from the micropoint of view, how Internet finance functions on the risk taking of commercial banks was illustrated. The existing papers focused more on the impact on commercial bank's business and functions exerted by Internet finance, lacking the discussion on the relation between Internet finance and commercial bank's risk taking. In this article, the author tried to offer the answer to such problem. By establishing the theoretical model including the Internet finance constraint, the author manifested the dynamic and heterogeneous influence on the risk taking of commercial bank brought by Internet finance, with a view to broadening the research perspective toward Internet finance and improving the theoretical framework of the risk taking of commercial bank.

(2) From the empirical point of view, the author verified the heterogeneous response made by commercial bank's risk taking toward Internet finance. The existing research based itself more on the empirical analysis about the complete sample of banking sector. In this article, the different influences exerted by Internet finance upon large and smalland-medium size commercial banks were interpreted, and reasonable explanations of such empirical result were delivered in light of the special background of China's banking sector, thus offering advices on further deepening the reform of commercial banks.

(3) From the perspective of financial function, the quantitative indicators measuring China's Internet finance development level were established. Despite that some scholars in China had already selected a certain data to represent the scope of Internet finance, these proxy variables merely included the payment function of the Internet, in neglect of other functions of that such as building channel, distributing resource, and managing risk. The author tried to make up for the deficiency in this article based on the thinking of financial function by way of "text mining" technology so as to establish Internet finance indicators, enabling us to have an objective measurement of the development level of Internet finance.

\section{Methods}

Theoretical model

Judging from the current situation, the course of development of China's Internet finance can be divided into three periods, namely, the Internet extension from the traditional financial service as the first period, booming development of Internet payment as the second period, and the emergence of Internet credit and Internet money management as the third one. Compared with developed countries such as Britain and America, China's Internet finance is still in its infancy. However, it develops and expands faster than expected, which has a bearing on the system of China's financial repression. Mckinnon (1973) and Shaw (1973) pointed out that there always existed financial repression in countries experiencing economic transformation. Xun and Johansson (2013) also held that, for a long time, there had been a phenomenon of severe financial repression in China's banking sector-higher entry barriers blocked potential competitors, and severe interest rate control lowered the cost of deposit which injected no impetus into commercial bank that enjoyed "monopoly bonus" and "price 
bonus" to shift technology, reduce cost, and upgrade efficiency. In this case, emerged Internet finance which expanded by leaps and bounds have left a profound influence on commercial bank.

In the period of the Internet extension from traditional finance service, the development of Internet finance is conducive to improving the technological level of commercial bank, bringing convenience to the way of service, and decreasing the management cost. Take online bank as an example, the built-up of this platform can help commercial bank to break through the limit of time and space, extend the customer chain, upgrade business process, facilitate data processing, and reduce service cost, thus achieving the management of informatization and intensification with efficiency and procedure. In the prosperous period of the third party payment, Internet finance not only replaces payment business of commercial bank but also, more crucially, "extracts" the current deposit of bank. Take the example of Alipay, this payment model meets the various payment requirements in society through flexible method and also distributes circulating funds into its own excess reserve account via its advantageous e-business platform, which reduces current deposit ratio and indirectly increases the cost of raising funds in bank. In the period when Internet credit and money management rose, Internet finance would speed up price competition, push forward the marketization of interest rate, and raise capital cost of commercial bank (Guoqiang and Pengfei 2014). Take the example of Yu Ebao, although this property management tool failed to have a huge impact on traditional finance in scale, the "catfish effect" it delivered had profoundly shaped capital pricing mechanism and the model of capital supply and demand, both of them in the charge of China's banks, having broken the revenue landscape of high interest margin enjoyed by banks and effectively driven the price marketization process.

To sum up, Internet finance influenced commercial banks through the following main channels, ranging from "upgrading technology level, improving work efficiency, reducing management cost" to "distributing current deposit, intensifying price competition and raising capital cost." In this case, how do these two channels influence risk taking of commercial banks? Based on "principal-agent theory," with management cost reduced and profit-making risen, commercial banks are less-motivated to transfer risks to depositors, thus reducing risk taking (Hellmann et al. 2000; Repullo 2004). And the "theory of competition fragility" indicated that the intense competition would lead to the decreased franchise value of bank, which would further encourage them to take more risks (Allen and Gale 2000). Hence, the preliminary conclusion were drawn-the effect of "reducing management cost" of Internet finance would lower the level of commercial bank's risk taking, but the effect of "raising capital cost" would increase the level of commercial bank's risk taking.

Meanwhile, relationship between the profit-making level, competition in market and risk taking were under the influence of various factors with bank such as capital scale, management strategy, and the requirement of monitoring (Ariss 2010; Jimenez et al. 2013). Instead, China's large and small-and-medium-sized commercial banks varied sharply in terms of property right structure, target customer and policy restriction, etc. Therefore, we deemed that distinct commercial banks would be heterogeneous in reaction to the impact brought by Internet finance. Upon the above analysis, Fig. 1 was drawn to illustrate how Internet finance influenced the risk taking of commercial bank. 


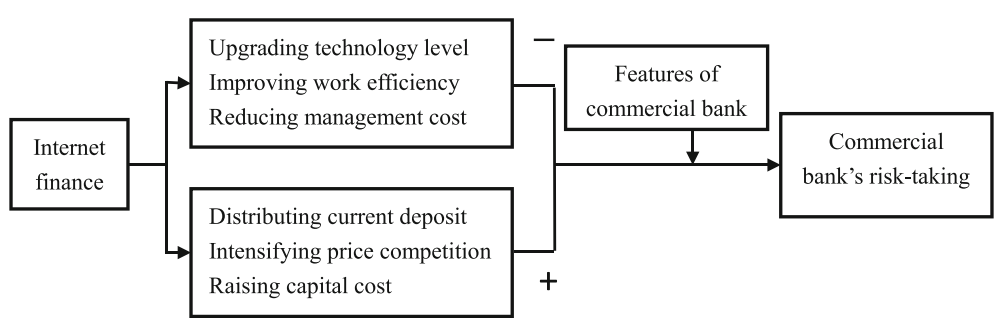

Fig. 1 Influence mechanism of Internet finance on commercial bank's risk taking

And it served as the basis to establish mathematical model in a bid to discuss the interrelation between the two sides.

In clarifying the effect of Internet finance on commercial bank's risk taking, the assumption of "internet finance constraint" and "commercial bank heterogeneity" was introduced into the model framework used by Kishan and Opiela (2000). The basic assumption goes as follows.

Assumption 1: Representative commercial bank accepted deposit D from household sector, raised equity capital E in capital market, and allocated these funds into business activities such as required reserve $\mathrm{R}$ and corporate loan $\mathrm{L}$, so as to achieve the maximum profit. The identical equation of assets and liabilities could be simplified as $R+L=D+E$. It was deemed that, without loss of generality, central bank did not pay deposit reserve interests; therefore, commercial bank only held reserve requirements, in other words, $R=\rho D$, with $\rho$ as reserve requirement ratio, $0<\rho<1$.

Assumption 2: Lending market constraint. It was until July 2013 that China completely freed its lending rate floor. However, according to the statistics from People's Bank of China, lending rate priced by floor rate only accounted for less than $25 \%$ over the past decade. ${ }^{1}$ So it turned out that the constraint of lending rate floor was ineffective in reality ( $\mathrm{He}$ and Wang 2012). In this situation, the higher the equilibrium lending rate $r_{L}^{*}$ in credit market was than lending price $r_{L}$, the bigger the amount of loan commercial bank would put on, namely, $L=L_{0}+L_{1}\left(r_{L}^{*}-r_{L}\right)$ and $L_{1}>0$. Meanwhile, $L_{0}$ differed in different types of banks, where more $L_{0}$ existed in big commercial banks while less in small ones. ${ }^{2}$

Assumption 3: Deposit market constraint. With long-term control of deposit rate, many scholars conducted empirical studies and concluded that in China, real interest rate was lower than equilibrium rate of interest, and it was effective to use deposit rate ceiling. Hence, the higher the market equilibrium interest rate $r^{*}$ was than deposit benchmark interest rate, the smaller deposit commercial bank would attract, namely, $D=D_{0}+D_{1}\left(r^{*}-\bar{r}_{D}\right)$ and $D_{1}<0$.

Assumption 4: Capital market constraint. The higher equilibrium interest rate $r_{E}^{*}$ of capital market than return on equity capital was, the smaller capital commercial bank would raise, namely, $E=E_{0}+E_{1}\left(r_{E}^{*}-r_{E}\right)$ and $E_{1}<0$. Furthermore, for a single commercial bank, $r_{L}^{*}, r_{E}^{*}$, and $r^{*}$ were exogenous, and $r_{L}^{*}$ and $r_{E}^{*}$ floated around $r^{*}$, namely, $r_{L}^{*}=r^{*}+\varepsilon_{L}$ and $r_{E}^{*}=r^{*}+\varepsilon_{E}$, with $\varepsilon_{L}$ and $\varepsilon_{E}$ as constant. 
Assumption 5: Management cost constraint. Representative commercial banks needed to pay cost $C$ of management and service fee. It was generally believed that the more deposit and lending were, the bigger cost $C$ would become. So based on scholars' common way, we set $C=(\omega / 2) D^{2}+(v / 2) L^{2}, \omega>0$, and $v>0$, which indicated unit marginal management cost of deposit and loan.

Assumption 6: Internet finance constraint. As Internet finance IF developed, on the one hand, it could improve management efficiency and reduce unit marginal management cost $\omega$ and $v$ in bank, namely, $\omega=\omega(I F)$ and $\partial \omega(I F) / \partial I F<0$ and $v=v(I F)$ and $\partial v(I F) / \partial I F<0$; on the other hand, it contributed to raise capital cost and correct the distortion of deposit price $\left(r^{*}-\bar{r}_{D}\right)$, namely, $\left(r^{*}-\bar{r}_{D}\right)=f(I F)$ and $\partial f(I F) / \partial I F<0$ (Nautz and Schmidt 2009; Nautz and Scheithauer 2011).

Accordingly, objective function and constraint conditions of representative commercial bank were supposed as follows:

$$
\begin{aligned}
& \operatorname{Max} \pi=r_{L} L-\bar{r}_{D} D-r_{E} E-C \\
& \operatorname{S.T}\left\{\begin{array}{l}
R+L=D+E, R=\rho D, 0<\rho<1 \\
L=L_{0}+L_{1}\left(r_{L}^{*}-r_{L}\right), L_{1}>0, r_{L}^{*}=r^{*}+\varepsilon_{L} \\
D=D_{0}+D_{1}\left(r^{*}-\bar{r}_{D}\right), D_{1}<0 \\
E=E_{0}+E_{1}\left(r_{E}^{*}-r_{E}\right), E_{1}<0, r_{E}^{*}=r^{*}+\varepsilon_{E} \\
C=(\omega / 2) D^{2}+(v / 2) L^{2}, \partial \omega / \partial I F<0, \partial v / \partial I F<0 \\
r^{*}-\bar{r}_{D}=f(I F), \partial f(I F) / \partial I F<0
\end{array}\right.
\end{aligned}
$$

Substituting the above constraint conditions (2) into objective function (1), then we get F.O.C of profit $\pi$ depending on $L$ :

$$
r^{*}+\varepsilon_{L}-\frac{2 L-L_{0}}{L_{1}}=r^{*}+\varepsilon_{E}+\frac{2(1-\rho)\left[D_{0}+D_{1} f(I F)\right]-2 L+E_{0}}{E_{1}}+v(I F) L
$$

The left part of formula (3) indicated marginal revenue of lending by commercial bank, and the right part indicated marginal cost of loan, including capital cost and management cost. According to formula (3), with the emergence of Internet finance, the capital cost of commercial bank would increase, while management cost declined. And then solve the best amount of credit supply $L^{*}$ of commercial bank:

$$
L^{*}=\frac{\Delta_{1}+\Delta_{2}\left[D_{0}+D_{1} f(I F)\right]}{\Delta_{3}-\Delta_{4} v(I F)}
$$

In this formula, $\Delta_{1}=\varepsilon_{E} L_{1} E_{1}-\varepsilon_{L} L_{1} E_{1}-L_{0} E_{1}+E_{0} L_{1}>0, \Delta_{2}=2 L_{1}(1-\rho)>0, \Delta_{3}=2 L_{1}-$ $2 E_{1}>0$, and $\Delta_{4}=L_{1} E_{1}<0$.

Based on formula (4), we reached the function about Internet finance IF and commercial banks' risk taking. ${ }^{3}$

$$
R I S K=\frac{R+L}{E}=1+\frac{\left[\Delta_{3}-\Delta_{4} v(I F)\right]\left[D_{0}+D_{1} f(I F)\right]}{\Delta_{1}+\left[\Delta_{5}+\Delta_{6} v(I F)\right]\left[D_{0}+D_{1} f(I F)\right]}
$$

In this formula, $\Delta_{5}=2 E_{1}(1-\rho)<0$ and $\Delta_{6}=L_{1} E_{1}(1-\rho)<0$.

First, we analyzed how Internet finance affected commercial bank's risk taking by "reducing management cost" and "raising capital cost" channels. And we now sought the first-order derivative of RISK via $v(I F)$ and $f(I F)$ and reached the following result: 


$$
\frac{\partial R I S K}{\partial v(I F)} \times \frac{\partial v(I F)}{\partial I F}=\frac{-\Delta_{1} \Delta_{4}\left[D_{0}+D_{1} f(I F)\right]-\Delta_{7}\left[D_{0}+D_{1} f(I F)\right]^{2}}{\left[\Delta_{1}+\left[\Delta_{5}+\Delta_{6} v(I F)\right]\left[D_{0}+D_{1} f(I F)\right]\right]^{2}} \times \frac{\partial v(I F)}{\partial I F}<0
$$

In this formula, $\Delta_{7}=2 L_{1}^{2} E_{1}(1-\rho)<0$.

Formula (6) indicated that Internet finance reduced the risk-taking level of commercial bank. That is to say, the brand-new technology thanks to the thriving Internet finance lowered the management cost of commercial bank, increased revenue level, and then weakened commercial bank's willingness to take risks.

$$
\frac{\partial R I S K}{\partial f(I F)} \times \frac{\partial f(I F)}{\partial I F}=\frac{\Delta_{1} D_{1}\left(\Delta_{3}-\Delta_{4} v\right)}{\left[\Delta_{1}+\left[\Delta_{5}+\Delta_{6} v(I F)\right]\left[D_{0}+D_{1} f(I F)\right]\right]^{2}} \times \frac{\partial f(I F)}{\partial I F}>0
$$

Formula (7) indicated that Internet finance increased the risk taking of commercial bank through "raising capital cost"; in other words, the emergence of Internet finance rationalized the market price mechanism and bridged the gap between deposit benchmark interest rate and market equilibrium interest rate, forcing commercial bank to enhance its risk-taking level for profit maintenance.

$$
\frac{\partial R I S K}{\partial I F}=\frac{\partial R I S K}{\partial f(I F)} \times \frac{\partial f(I F)}{\partial I F}+\frac{\partial R I S K}{\partial v(I F)} \times \frac{\partial v(I F)}{\partial I F}>,=,<0
$$

Formula (8) indicated that how Internet finance affected commercial bank's risk taking was co-determined by "reducing management cost" and "raising capital cost" channels. Looking at the progress of Internet finance in China, "reducing management cost" played a crucial role in the period of Internet extension from traditional finance, where bank would take less risk as Internet finance grew. In the period of Internet payment, Internet credit, and Internet wealth management, "raising capital cost" would be a priority, as bank would get impacted by Internet finance to take even more risk. In so doing, there appeared a down-and-up $U$ curve trend demonstrating how Internet finance affected commercial bank to take risk.

Second, we analyzed what heterogeneous response that different commercial bank made toward Internet finance. It was not hard to find that $\Delta_{1}$ in both formula (6) and formula (7) included variable $L_{0}$ which distinguished different commercial banks. So we took the derivative of formula (6) and formula (7) in order to interpret those responses by commercial banks:

$$
\begin{aligned}
& \partial\left(\frac{\partial R I S K}{\partial v(I F)} \times \frac{\partial v(I F)}{\partial I F}\right) / \partial L_{0}=\frac{-E_{1} \Delta_{4} \Delta_{8} D^{2}-2 E_{1} \Delta_{7} D^{3}}{\Delta_{9}{ }^{3}} \times \frac{\partial \nu(I F)}{\partial I F}>0 \\
& \partial\left(\frac{\partial R I S K}{\partial f(I F)} \times \frac{\partial f(I F)}{\partial I F}\right) / \partial L_{0}=\frac{E_{1} \Delta_{8} D_{1}\left(\Delta_{3}-\Delta_{4} v\right)}{\Delta_{9}{ }^{3}} \times \frac{\partial f(I F)}{\partial I F}<0
\end{aligned}
$$

In this formula, $\Delta_{8}=\Delta_{1}-\left[\Delta_{5}+\Delta_{6} v(I F)\right] D>0, \Delta_{9}=\frac{E}{\left[\Delta_{3}-\Delta_{4} v(I F)\right]}=\Delta_{1}+\left[\Delta_{5}+\Delta_{6} v(I F)\right]$ $D>0$.

Formula (9) and (10) indicated that as $L_{0}$ increased, Internet finance would decreasingly affect commercial bank to take risk. In other words, big commercial banks turned out to be slow to take risk responding to the impact of Internet finance, while it was not the case with small-and-medium-sized commercial banks, which showed relatively obvious reaction. There were some explanations to this end: first, nominal ownership of big commercial banks, long chain of principal agent, and implicit government 
guarantee as well as the expectation of "too big to fail" would weaken the restriction of budget, leading to slow reaction to market competition (Zhixian et al. 2015). Second, big commercial banks were large in system, diverse in management level, and various in personnel structure, so they were easily to have time lag in signaling and tackling crisis (Mulherin and Boone 2000). Third, big commercial banks, generally speaking, eyed for big SOEs; while small-and-medium-sized commercial banks and Internet finance always treated micro-small-and-mediumsized enterprises as their customers. Thus, Internet finance had an ever immediate impact on small-and-medium-sized enterprises. Fourth, big commercial banks were subject to strict policies of supervision as systematically important banks. According to the study of Beltratti and Stultz (2012), the tighter the supervision was, the more prudent risk-taking behaviors those economic subjects would make. Therefore, nominal ownership, large scale, fixed customer, and special status together resulted that big commercial banks' risk taking were slow in responding Internet finance.

Based on the above theories and models, two propositions were proposed hereby to be further examined.

Proposition 1: Viewed from the dynamic evolution standpoint, Internet finance had a "U"-shaped trend impact on the risk taking of commercial banks; in other words, Internet finance was, in its infancy, conducive to commercial banks to cut down management cost and reduce risks they shouldered, but then, Internet finance would raise capital cost and also the risk taking for commercial banks.

Proposition 2: Viewed from the horizontal dimension, confronted by the impact of Internet finance, different commercial banks were heterogeneous in their risk-taking reaction: big commercial banks were slow whereas small-and-medium-sized ones were quick to make response.

\section{Emprical methods}

Having ruled out some banks with a few information, 36 Chinese commercial banks were chosen as the sample, including five big commercial banks as ICBC (Industrial and Commercial Bank of China), ABC (Agricultural Bank of China), BOC (Bank of China), CBC (Construction Bank of China), and BOC (Bank of Communications), and 31 small-and-medium-sized commercial banks such as China Ever-bright Bank, Guangdong Development Bank, Industrial Bank, Bank of Dalian, Fudian Bank, and Bank of Nanjing. All these samples selected spanned from 2003 to 2013.

\section{(1)Proxy variable of bank's risk taking}

The $Z$-value, expected probability of default (EDF), net-lending/asset ratio, loanloss reserve ratio, and asset/equity ratio $\left(R I S K_{A / E}\right)$ were selected in existing papers to measure how commercial banks take risks. Yet $Z$-value merely mirrored the bankruptcy risk rather than entire risks facing banks. Lagging behind in domestic credit rating explained why those EDF statistics could hardly be gained. Given this situation, hereafter, this paper would adopt $R_{I S K_{A / E}}$ as the major proxy variable with respect to risk taking and also RISK $_{L L}$ and RISK $_{L / A}$ as auxiliary proxy variables 
for the sake of reliable conclusion in this study. ${ }^{4}$ These data came from BankScope database and statements of commercial banks.

(2) Proxy variable of Internet finance

Internet finance was absent from coordinated, standard, and comprehensive data statistics due to multi-forms and surfacing innovation in this regard. Among empirical studies, only a small number of them use the third-party payment limitation or the ratio between Internet payment and online-banking transaction to reflect the development of Internet finance. These kinds of indicators were worth of reference, but they only included the payment function of Internet without considering other functions such as building channels, allocating resources, and managing risks. By evaluating the overall and feasible factors, therefore, this paper would take use of the indicators from "text mining" as proxy variable for Internet finance from the perspective of financial function.

First and foremost, the Internet finance models shall be divided and original lexicons established on the basis of financial function view. Academic circles were varied in their opinions toward the divisions of such models. The fact that Internet finance played its role by providing and perfecting the financial function allowed us to comb through China's Internet finance model based on financial function view proposed by Merton and Bodie (1995) and set up the original lexicons as Table 1. First of all, at present, China commercial banks can pass price information and enhance interactive efficiency through online banking, electronic banking, and other network channels, which is the best embodiment of channel building function. Second, third-party payment, like Ali pay, and Union Pay payment can provide more flexible, more convenient and wider payment, and clearing and settlement services for goods and asset transactions. Third, P2P, crowdfunding, and other online loan can achieve intertemporal, cross-regional, and cross-sectoral capital transfer and optimize the allocation of social resources. Finally, Internet insurance, online futures, and other Internet financial management methods not only enrich the demand structure of financial management through personalized products but also expand the supply scale of financial management by means of convenient marketing network, both of which are conducive to Internet financial management function.

Second, word frequency could be calculated and lexicons quantified by means of Baidu search engine. According to a study made by Askitas and Zimmermann (2009), the number of news released implied demand information related to netizens and supply information related to enterprise input. So in the era when Internet acted as the major media of information spreading, the more numbers of

Table 1 Original lexicons of Internet finance based on financial function view

\begin{tabular}{lllll}
\hline Financial function & Channel building & Payment clearing & Resource allocation & Financial management \\
\hline Division of models & Internet channel & Internet payment & Internet credit & $\begin{array}{l}\text { Internet wealth } \\
\text { management }\end{array}$ \\
Original lexicons & Internet banking & Online payment & Internet loan & $\begin{array}{l}\text { Online wealth } \\
\text { management }\end{array}$ \\
& Electronic banking & Mobile payment & Internet financing & $\begin{array}{l}\text { Internet wealth } \\
\text { management }\end{array}$ \\
& Online banking & Third-party payment & Internet investment & Internet insurance \\
\hline
\end{tabular}


online news including original lexicons in Table 1, the better situation we would achieve in terms of financial development. Thus, the number of news which contained original key words from 2003 to 2013 in the Baidu database and the total amount of yearly news were calculated hereby and got the yearly word frequency by comparing the above two figures so as to quantify each and every key word. $^{5}$

Finally, different kinds of Internet finance indicators could be created by way of factor analysis. (1) Analyze the above 12 key words based on factor analysis and estimate the trend of the development of Internet finance. First, test data. As was shown in Table 2, when the KMO figure was 0.79, the Bartlett figure was 202.93, which meant some elements were shared among key words. Second, extract common factors. Based on principal component analysis, extract common factors whose eigenvalue outnumbered 1. Result had it that contribution ratio of variance was registered at $86.53 \%$, and it could reflect a majority of original information. Third, calculate factor scores. Conduct orthogonal rotation targeted at rotated component matrix in line with maximum variance principle and then get the estimated component score coefficient matrix through regression analysis. Fourth, composite index. Set factor score as the weight and describe the common factor as the linear combination of original variables. Meanwhile, we could standardize figures as between 0 and 1 by means of the maximum and minimum principle, in order to get the index of finance (IF). (2) Conduct factor analysis toward key words in all dimensions, so as to measure the level of four models of Internet finance. The result was shown in Table 2.

Figure 2 showcased how the index of Internet finance developed in accordance with the technology of "text mining." It basically matched the growth of Internet finance in China. Prior to 2008, commercial banks pressed ahead with the online business, where the Internet channel index held a safe lead; during 2009 to 2010, the third party payment began to spring up, when the Internet payment index succeeded to overtake those figures; from 2011 to 2013, the business of online investment and Internet finance swiftly expanded, and the Internet credit and Internet wealth management index sharply increased

(3) Control variables

Based on the current literature, inevitably, factors such as the monetary policy change, macro-economic development, the degree of interest rate liberation, competition level in industries, and micro-characteristics of banks as well affected

Table 2 Factor analysis of the index of Internet finance

\begin{tabular}{|c|c|c|c|c|c|}
\hline Index & $\begin{array}{l}\text { Internet } \\
\text { finance } \\
\text { index }\end{array}$ & $\begin{array}{l}\text { Internet } \\
\text { channel } \\
\text { index }\end{array}$ & $\begin{array}{l}\text { Internet } \\
\text { payment } \\
\text { index }\end{array}$ & $\begin{array}{l}\text { Internet } \\
\text { credit } \\
\text { index }\end{array}$ & $\begin{array}{l}\text { Internet wealth } \\
\text { management index }\end{array}$ \\
\hline KMO figure & 0.79 & 0.81 & 0.74 & 0.84 & 0.80 \\
\hline $\begin{array}{l}\text { Bartlett statistics } \\
\text { (figure } P \text { ) }\end{array}$ & $202.93^{* * *}(0.00)$ & $16.82^{* * *}(0.00)$ & $18.84^{* * *}(0.00)$ & $28.34^{* * *}(0.00)$ & $15.77^{* * *}(0.00)$ \\
\hline $\begin{array}{l}\text { Number of common } \\
\text { factors }\end{array}$ & 1 & 1 & 1 & 1 & 1 \\
\hline $\begin{array}{l}\text { Variance contribution } \\
\text { ratio }\end{array}$ & $86.53 \%$ & $93.47 \%$ & $85.19 \%$ & $91.77 \%$ & $92.53 \%$ \\
\hline
\end{tabular}

Note: ${ }^{* *}$ represents significance at $1 \%$ levels. 


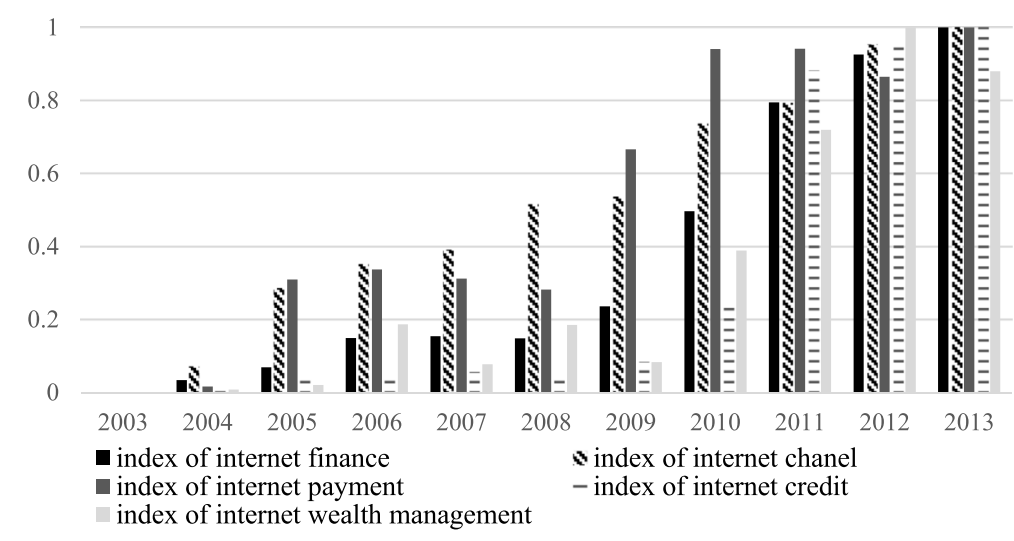

Fig. 2 Development of Internet finance in China between 2003 and 2013

the behavior of risk taking. To this end, the chosen control variables in this paper include the following: increase rate of broad money supply which indicated the tightness of monetary policy (M2), nominal GDP growth rate which reflected the level of macro-economy development (GDP), interest rate liberation index which showed the degree of interest-rate liberation (IRL), growth rate of share of asset among the top four banks which mirrored the competition level in industries (CR4), increase rate of the number of foreign-invested banks in China (FORE), and also the ratio between liquid assets and total assets which depicted banks' micro-characteristics (LI). ${ }^{6}$ Among them, the index of interest rate liberation level was reached according to the study made by Shujun and Jiangang (2014), with other data deriving from NBS website, CEINET database, China's financial statistical yearbook, BankScope database, and annual statements of various commercial banks.

Proposition 1 indicated that Internet finance's impact on the risk that commercial bank took presented a $U$ trend. To verify proposition 1, the following econometric model formula (11) was set up.

$$
\operatorname{RISK}_{i t}=\beta_{0}+\beta_{1} \operatorname{RISK}_{i, t-1}+\beta_{2} \operatorname{RISK}_{i, t-2}+\beta_{3} I F_{t}+\beta_{4} I F_{t}^{2}+\beta_{5} X_{i t}+\lambda_{i}+\chi_{t}+\varepsilon_{i t}
$$

In this formula, $R I S K_{i t}$ is the bank $i$ 's risk-taking level in the year of $t, I F_{t}$ is the Internet finance index in the year $t, X_{i t}$ is a series of control variables, $\lambda_{i}$ is the individual fixed effect, $\chi_{t}$ is the time fixed effect, and $\varepsilon_{i t}$ is the stochastic error term. As was studied by Delis and Kouretas (2011), relationship lending and fierce competition would trigger consistent risks. Therefore, the first and second lagged variables as regards commercial banks' risk taking were introduced here in this paper. According to theoretical analysis, the coefficient regression of $\beta_{3}$ was expected to be significantly negative, with the expected result of $\beta_{4}$ significantly being positive.

Proposition 2 showed that Internet finance played a heterogeneous role in affecting risk-taking behavior of different types of commercial banks. In order to verify proposition 
2, interaction items of Internet finance index and dummy variable of bank kinds were introduced into formula (11). The empirical equation was set below:

$$
\begin{aligned}
& \operatorname{RISK}_{i t}=\beta_{0}+\beta_{1} R_{1 S K_{i, t-1}}+\beta_{2} R_{I S K_{i, t-2}}+\beta_{3} I F_{t}+\beta_{4} I F_{t} \times K_{i} \\
& +\beta_{5} I F_{t}^{2}+\beta_{6} I F_{t}^{2} \times K_{i}+\beta_{7} X_{i t}+\lambda_{i}+X_{t}+\varepsilon_{i t}
\end{aligned}
$$

Here, in this equation, $K_{i}$ referred to the kind of bank $i$. When the sample bank was large-scaled commercial bank, then we assume $K$ as 1 and in other situations as 0 . After the above analysis, we expected that $\beta_{4}$ was significantly positive and $\beta_{6}$ significantly negative.

Since dependent variable lagged items served as the explanatory variables in formula (11) and (12), the cross section dependency and endogenous problems were easy to occur in empirical equations. In this situation, the adoption of traditional data estimation method would lead to deviation including mixed effect model, fixed effect model and random effect one; hence, the explanation viewed from economics done was bound to be far from scientific. In comparison, SYSGMM method used by Blundell and Bond (1998), Arellano and Bond (2004) not only allowed the existence of serial correlation and heteroscedasticity in data but also helped the endogenous problem-solving by way of proper instrument, thus significantly reducing the biasedness of estimated coefficient. In so doing, the SYSGMM method was chosen so as to interpret the relation between variables.

\section{Results and discussion}

\section{Stability test of variables}

The precondition of estimating dynamic panel model is the stability of data. To this end, the Hadri test, LLC test, and IPS test at bank level were implemented. Table 3 demonstrated that proxy variables of risk taking and liquidity level of commercial banks were all stable series at the significant level of $1 \%$, excluding the possibility of "fake regression" model.

\section{Empirical study about Internet finance's dynamic impact on commercial bank's risk-taking behavior}

Table 4 reported the regression result of proposition 1 . Models (1) and (2) are the benchmark regression results taking RISK $_{A / E}$ as bank's risk-taking proxy variables. According to Table 4, among these two models, the regression coefficients of the first and second lagged items of dependent variable were significantly positive, demonstrating that the risk-taking behavior was indeed of sustainability; the figure $P$ of AR (2) test

\begin{tabular}{|c|c|c|c|}
\hline \multirow[t]{2}{*}{ Variables } & Hadri test & LLC test & IPS test \\
\hline & Statistics (figure $P$ ) & Statistics (figure $P$ ) & Statistics (figure $P$ ) \\
\hline$R I S K_{A / E}$ & $2.327^{* * *}(0.010)$ & $-8.883^{* * *}(0.000)$ & $-4.229^{* * *}(0.000)$ \\
\hline$R I S K_{L L}$ & $7.787^{* * *}(0.000)$ & $-30.396^{* * *}(0.000)$ & $-7.206^{* * *}(0.000)$ \\
\hline RISKL/A & $8.636^{* * *}(0.000)$ & $-7.139^{* * *}(0.000)$ & $-3.522^{* * *}(0.000)$ \\
\hline LI & $8.000^{* * *}(0.000)$ & $-6.152^{* * *}(0.000)$ & $-1.764^{* *}(0.039)$ \\
\hline
\end{tabular}

Table 3 Variables unit root test

Note: The original assumption of three types of unit root test was the non-existence of unit root of variables; ${ }^{* *}$ and ** represent significance at 1 and $5 \%$ levels, respectively 
Table 4 Results of Internet finance's dynamic impact on commercial banks' risk taking

\begin{tabular}{|c|c|c|c|c|c|c|}
\hline Variable & Model (1) & Model (2) & Model (3) & Model (4) & Model (5) & Model (6) \\
\hline \multirow[t]{2}{*}{ L1.RISK } & $0.2164^{* * *}$ & $0.2101^{* * *}$ & $0.7195^{* * *}$ & $0.8478^{* * *}$ & $0.5135^{* * *}$ & $0.4362^{* * *}$ \\
\hline & $(0.0025)$ & $(0.0106)$ & $(0.0106)$ & $(0.0099)$ & $(0.0200)$ & (0.0195) \\
\hline \multirow[t]{2}{*}{ L2.RISK } & $0.1047^{* * *}$ & $0.0939^{* * *}$ & $0.1654^{* * *}$ & $0.1692^{* * *}$ & $0.0742^{* * *}$ & $0.0557^{* * *}$ \\
\hline & $(0.0036)$ & $(0.0049)$ & $(0.0022)$ & $(0.0033)$ & $(0.0134)$ & $(0.0076)$ \\
\hline \multirow[t]{2}{*}{ IF } & $-0.2223^{* * *}$ & $-30.1231^{* * *}$ & $-0.0035^{* * *}$ & $-0.0366^{* * *}$ & $-0.0850^{* * *}$ & $-7.3493^{* *}$ \\
\hline & $(0.0185)$ & (2.3049) & $(0.0007)$ & $(0.0040)$ & $(0.0164)$ & (3.1677) \\
\hline \multirow[t]{2}{*}{$\mathbb{I F}^{2}$} & $0.1569^{* * *}$ & $32.8704^{* * *}$ & $0.0031^{* * *}$ & $0.0513^{* * *}$ & $0.0255^{*}$ & $7.9062^{* *}$ \\
\hline & $(0.0136)$ & (2.4995) & $(0.0007)$ & (0.0059) & $(0.0146)$ & $(3.4574)$ \\
\hline \multirow[t]{2}{*}{ M2 } & & $78.8531^{* * *}$ & & $0.1627^{* * *}$ & & $18.8744^{* *}$ \\
\hline & & (5.9788) & & $(0.0176)$ & & (8.3045) \\
\hline \multirow[t]{2}{*}{ GDP } & & $69.1355^{* * *}$ & & $0.1392^{* * *}$ & & $16.2992^{* *}$ \\
\hline & & (5.2319) & & $(0.0180)$ & & (7.2208) \\
\hline \multirow[t]{2}{*}{ IRL } & & $1.3581^{* * *}$ & & $0.0060^{* *}$ & & $0.3046^{* * *}$ \\
\hline & & $(0.1395)$ & & $(0.0021)$ & & $(0.0186)$ \\
\hline \multirow[t]{2}{*}{ CR4 } & & $-0.2378^{* * *}$ & & $0.0022^{* * *}$ & & $-0.0892^{* * *}$ \\
\hline & & $(0.0248)$ & & $(0.0004)$ & & $(0.0278)$ \\
\hline \multirow[t]{2}{*}{ FORE } & & $-28.3608^{* * *}$ & & $-0.0290^{* * *}$ & & $-7.2150^{* *}$ \\
\hline & & $(2.2229)$ & & $(0.0033)$ & & $(2.9662)$ \\
\hline \multirow[t]{2}{*}{ LI } & & $-0.0427^{* * *}$ & & $-0.0131^{* * *}$ & & $-0.2629^{* * *}$ \\
\hline & & $(0.0147)$ & & $(0.0016)$ & & $(0.0290)$ \\
\hline Individual fixed effect & Control & Control & Control & Control & Control & Control \\
\hline Time fixed effect & Control & Control & Control & Control & Control & Control \\
\hline \multirow[t]{2}{*}{ AR2 test } & -0.7297 & -1.0136 & -0.9811 & -0.6236 & 0.1376 & -0.8907 \\
\hline & $(0.4656)$ & $(0.3110)$ & $(0.3266)$ & $(0.5329)$ & $(0.8906)$ & $(0.3731)$ \\
\hline \multirow[t]{2}{*}{ Sargan test } & 27.8502 & 27.2150 & 36.3178 & 26.7258 & 31.2279 & 32.5433 \\
\hline & $(0.3659)$ & $(0.3981)$ & $(0.1906)$ & $(0.5332)$ & $(0.2199)$ & $(0.1758)$ \\
\hline
\end{tabular}

Note: Under the regression coefficient sit the standard error within bracket; beneath the model test was figure $P$; constant term was omitted in the regression result; ${ }^{* * *},{ }^{* *}$, and * represent significance at 1,5 , and $10 \%$ levels, respectively

and Sargan test were both above 0.1, indicating that the second-order autocorrelation in the difference of disturbing terms and over-recognition in instrumental variables did not exist. Hence, the dynamic empirical model in this paper was both necessary and reasonable.

First, model (1) merely considered the relation between Internet finance and commercial bank's risk-taking behavior. The monomial coefficient $(I F)$ and quadratic coefficient $\left(I F^{2}\right)$ of Internet finance were, respectively, negative and positive, both of them having passed the significance test at the level of $1 \%$. This result was in line with the expectation of proposition 1 and tested the U-type relation between Internet finance and risk-taking behavior of commercial banks, which showed that the initial development of Internet finance could lessen the burden of commercial bank's risks, while the further progress of Internet finance could aggravate the risks.

Next, control variables were added into model (2), with the result showing that the regression marks and significance level of monomial coefficient and quadratic coefficient of Internet finance remained unchanged. It again proved the proposition 1 did come into existence. Based on the estimated result of model (2), the inflection point of 
the quadratic function was 0.9164 , slightly lower than the Internet finance index in 2012. Fact showed that the parabola of model (2) was upward, so the preliminary prediction was drawn that from 2003 to 2011, the Internet finance development was conducive for banks to decrease risks they shouldered, whereas in 2012 to 2013, the impact deriving from such development would further intensify the relevant risks. According to Fig. 2 where the growth of Internet finance was illustrated, prior to 2010, China's Internet channel index was far higher than Internet credit index and Internet wealth management index. Therefore, in this period, Internet finance lowered the management cost of bank by improving technological level and work efficiency, hence dampening the willingness of commercial banks to take the risks. Following 2011, booming Internet credit and Internet wealth management index overtook the Internet channel index. It explained why the capital cost in bank was uplifted and commercial banks forced to resist more risks to maintain profit, due to the fact that current deposit was distributed and distorted interest rate corrected. And as manifested by theory and empirical analysis, from the perspective of dynamic evolution, Internet finance's impact on risk taking of banks was not a simple linear relation, but a U-type trend upward after downward.

Besides, the regression result of control variables was basically corresponding with the existing studies. The coefficient of monetary supply increase rate $\left(M_{2}\right)$ was significantly positive at the level of $1 \%$, symbolizing that China's monetary policy was not neutral and too proactive policy would level up commercial bank's risk tolerance scale. Plus, the regression coefficient of macro-economic growth rate (GDP) was significantly positive. According to the research of López et al. (2011), upward economic tendency would boost the optimism of commercial banks and encourage them to undertake excessive risks. And the coefficient of IRL level was positive which also passed the significance test at $1 \%$ level. The cancelation of interest rate control tightened the interest margin between deposits and loans and further raised the credit risk among banks.

Furthermore, the significant negative results of the concentration ratio of industry (CR4) and industrial openness (FORE) reflected more intense competition in industries always companied with lower risks confronting commercial banks. For one thing, the management efficiency would be improved and exposure of risks decreased as market competition intensified (Berger et al. 2009); for another, foreign-invested banks involvement would increase the risk-control skills for domestic banks and stabilize the healthy operation. Also, the coefficient of liquidity level $(L I)$ was negative and highly significant in statistics. As mentioned by Mussa (2011), as liquidity risk was one of the major risks in banks, more abundant the liquidity was, lower risk-taking level the commercial banks have to face.

In order to ensure the robustness of study result, first, loan-loss reserve rate $\left(R I S K_{L L}\right)$ and risk asset ratio ( RISK $_{L / A}$ ) were considered as alternative variables to banks' risk taking, with result been listed in model (3) and model (6) in Table 4. Second, processed Winsor sample under $5 \%$ would be regressed. Study showed that the estimated monomial coefficient of Internet finance $(I F)$ was significantly negative, while quadratic term $\left(I F^{2}\right)$ significantly positive, with the result of control variables unchanged. ${ }^{7}$ The robust test again verified proposition 1 , indicating that the study conclusion would not alter due to changes of risk-taking variables in banks. 


\section{Empirical analysis of Internet finance's heterogeneous impact on commercial banks' risk-taking behavior}

Table 5 listed the regression result of proposition 2. Model (7) was a benchmark analysis where the ratio between asset and equity was used as explanatory variables. And AR (2) test and Sargan test both revealed the rationality of the empirical equation. Among them, interaction term $I F \times K$ 's regression coefficient proved significantly positive, and the coefficient of $I F^{2} \times K$ significantly negative. This result was in accord with the expectation of proposition 2, which explained that in the face of the Internet finance's impact, different kinds of commercial banks' risk taking would respond distinctly. In respect of large commercial banks, their responses were a little bit slow due to the dysfunctional ownership, large scale, fixed customer base, and the stringent surveillance. While the small-and-medium-sized banks were comparatively sensitive. In

Table 5 Results of Internet finance's heterogeneous impact on commercial banks' risk taking

\begin{tabular}{|c|c|c|c|c|c|c|}
\hline Variable & Model (7) & Model (8) & Model (9) & Model (10) & Model (11) & Model (12) \\
\hline \multirow[t]{2}{*}{ L1.RISK } & $0.2042^{* * *}$ & $0.8134^{* * *}$ & $0.4123^{* * *}$ & $0.1925^{* * *}$ & $0.7914^{* * *}$ & $0.4244^{* * *}$ \\
\hline & $(0.0180)$ & $(0.0129)$ & $(0.0241)$ & $(0.0212)$ & $(0.0117)$ & $(0.0206)$ \\
\hline \multirow[t]{2}{*}{ L2.RISK } & $0.0937^{* * *}$ & $0.1409^{* * *}$ & $0.0480 * * *$ & $0.1416^{* * *}$ & $0.1555^{* * *}$ & $0.0754^{* * *}$ \\
\hline & $(0.0071)$ & $(0.0146)$ & $(0.0122)$ & $(0.0076)$ & (0.0199) & $(0.0123)$ \\
\hline \multirow[t]{2}{*}{ IF } & $-29.5753^{* * *}$ & $-1.9488^{* * *}$ & $-8.6732^{* * *}$ & $-37.9363^{* * *}$ & $-2.3629 * * *$ & $-11.7531^{* * *}$ \\
\hline & (3.1639) & $(0.2472)$ & (3.2313) & $(1.8582)$ & $(0.2915)$ & (3.0525) \\
\hline \multirow[t]{2}{*}{$\mathbb{F}^{2}$} & $32.2653^{* * *}$ & $2.1361^{* * *}$ & $9.3516^{* * *}$ & $41.4076^{* * *}$ & $2.5910^{* * *}$ & $12.7041^{* * *}$ \\
\hline & (3.4387) & $(0.2693)$ & (3.5244) & (2.0135) & $(0.3174)$ & (3.3185) \\
\hline \multirow[t]{2}{*}{$I F \times K$} & $0.0503^{* * *}$ & $0.0113^{* *}$ & $0.1667^{* * *}$ & & & \\
\hline & $(0.0041)$ & $(0.0045)$ & $(0.0446)$ & & & \\
\hline \multirow[t]{2}{*}{$I^{2} \times K$} & $-0.0661^{*}$ & $-0.0019^{* * *}$ & $-0.0833^{* *}$ & & & \\
\hline & $(0.0352)$ & $(0.0033)$ & $(0.0344)$ & & & \\
\hline \multirow[t]{2}{*}{ M2 } & $77.4084^{* * *}$ & $5.1755^{* * *}$ & $22.3141^{* * *}$ & $99.4639^{* * *}$ & $6.2661^{* * *}$ & $30.3136^{* * *}$ \\
\hline & $(8.2261)$ & $(0.6457)$ & $(8.4614)$ & $(4.8040)$ & $(0.7626)$ & (7.9617) \\
\hline \multirow[t]{2}{*}{ GDP } & $67.8745^{* * *}$ & $4.4807^{* * *}$ & $19.2978^{* * *}$ & $87.2799^{* * *}$ & $5.4303^{* * *}$ & $26.2671 * * *$ \\
\hline & (7.1875) & $(0.5627)$ & $(7.3569)$ & (4.2009) & $(0.6626)$ & $(6.9081)$ \\
\hline \multirow[t]{2}{*}{ IRL } & $1.3712^{* * *}$ & $0.0766^{* * *}$ & $0.3056^{* *}$ & $1.8193^{* * *}$ & $0.0852^{* * *}$ & $0.4283^{* * *}$ \\
\hline & $(0.1567)$ & $(0.0134)$ & $(0.1289)$ & $(0.1269)$ & $(0.0137)$ & $(0.1607)$ \\
\hline \multirow[t]{2}{*}{ CR4 } & $-0.2353^{* * *}$ & $-0.0155^{* * *}$ & $-0.0936^{* * *}$ & $-0.3051^{* * *}$ & $-0.0177^{* * *}$ & $-0.1203^{* * *}$ \\
\hline & $(0.0309)$ & $(0.0024)$ & $(0.0295)$ & $(0.0205)$ & $(0.0028)$ & $(0.0320)$ \\
\hline \multirow[t]{2}{*}{ FORE } & $-27.8407^{* * *}$ & $-1.8230^{* * *}$ & $-8.3868^{* * *}$ & $-35.7035^{* * *}$ & $-2.2065^{* * *}$ & $-11.3062^{* * *}$ \\
\hline & (3.0072) & $(0.2367)$ & (3.0313) & (1.7970) & $(0.2747)$ & (2.9053) \\
\hline \multirow[t]{2}{*}{ LI } & $-0.0242^{* *}$ & $-0.0143^{* * *}$ & $-0.2443^{* * *}$ & $-0.0228^{* *}$ & $-0.0180^{* * *}$ & $-0.2530^{* * *}$ \\
\hline & $(0.0027)$ & $(0.0028)$ & $(0.0338)$ & $(0.0016)$ & $(0.0030)$ & (0.0308) \\
\hline Individual fixed effect & Control & Control & Control & Control & Control & Control \\
\hline Time fixed effect & Control & Control & Control & Control & Control & Control \\
\hline \multirow[t]{2}{*}{ AR2 test } & -1.2650 & -0.0583 & -0.2554 & -1.2698 & 0.0837 & -1.0268 \\
\hline & $(0.2059)$ & $(0.9535)$ & $(0.7984)$ & $(0.2057)$ & (0.9333) & $(0.3045)$ \\
\hline \multirow[t]{2}{*}{ Sargan test } & 27.0726 & 20.5812 & 25.9352 & 23.3621 & 18.0236 & 22.3627 \\
\hline & $(0.4055)$ & $(0.7632)$ & $(0.4667)$ & $(0.6124)$ & $(0.8749)$ & $(0.6687)$ \\
\hline
\end{tabular}

Note: Under the regression coefficient sit the standard error within bracket; beneath the model test was figure $P$; constant term was omitted in the regression result; ${ }^{* * *},{ }^{* *}$, and * represent significance at 1,5 , and $10 \%$ levels, respectively 
the meanwhile, the monomial coefficient of Internet finance proved significantly negative and quadratic one significantly positive, further backing the proposition 1 . It was needless to say that the regression mark and significance level of control variables were basically the same as the result of Eq. (11).

In order to guarantee the reliability of the conclusion, the robustness test was conducted from the following three aspects. First, the RISK $_{L L}$ and RISK $_{L / A}$ were treated as the alternative indicator in terms of banks' risk-taking behavior, with result shown in models (8) and (9). We found that the coefficient of interaction item $I F \times K$ in the regression result was still significantly positive, while the coefficient of $I F^{2} \times K$ significantly negative. Second, with 31 small-and-medium-sized commercial banks as sample, $R I S K_{A / E}, R_{I S K_{L L}}$, and $R I S K_{L / A}$ constituted of explained variables to estimate Eq. (11), results being seen from models (10) to (12). It was not uneasy to discern that compared with the regression result of the complete sample (the second, fourth, and sixth row in Table 4), the monomial (IF) and quadratic coefficient $\left(I F^{2}\right)$ of Internet finance were significantly increased in absolute term and highly significant in speaking of statistics, further supporting proposition 2. Third, system GMM technique was used for estimating Eq. (12) based on the sample of processed Winsor under $5 \%$ level, and no marked changes were noticed among regression coefficients of all variables. ${ }^{8}$ Such robustness test result echoed the benchmark study, which illustrated that from the dimension of horizontal comparison, different types of commercial banks differed in risk taking in responding to Internet finance.

\section{Conclusions}

At an unprecedented scale, the Internet brought about a profound revolution worldwide; finance, the origin of all industries, would inevitably be involved this time. Besides, the "uncultivated" growth of China's Internet finance in recent years put itself under the spotlight of the entire society. Explosive development of Internet finance rapidly shaped the original financial ecology, having a great impact on the traditional businesses of commercial banks which were forced to make changes. These banks tried to radicalize their business behaviors and shift risk-control strategies to maintain profits. Under this background, it carried both theoretical and realistic value to study the relation between Internet finance and commercial banks' risk-taking behavior.

Considering this, in this paper, the Internet finance restraint and heterogeneity assumption were introduced into the theoretical model of Kishan and Opiela (2000) to analyze the dynamic and heterogeneous influence on commercial banks for bearing risks from Internet finance. On this basis, 36 commercial banks from 2003 to 2013 were selected as sample for empirical analysis, with Internet finance index setting up by "text mining method" as explanatory variable and SYSGMM as methodology. The conclusions were arrived at as follows: (1) through the lens of dynamic evolution, the downward-to-upward $U$ trend was found in regard to the impact of China commercial banks' risk taking delivered by Internet finance. In other words, Internet finance was, in its infancy, helpful for commercial banks to cut down management cost and reduce risk taking, but then, Internet finance would raise capital cost and also the risk taking for commercial banks. (2) Viewed from the perspective of horizontal comparison, different types of commercial banks were heterogeneously responding to Internet finance. 
Some large commercial banks were slow while small and medium sized ones comparatively sensitive.

The conclusion showed the complexity of the implication mechanism and functional process of how Internet finance affected China commercial banks' risk taking. Some differences could be seen apart from those similarities regarding the responses made by various kinds of commercial banks to Internet finance during different periods of time. And the hidden political implications remained as follows.

First, supervision department should grasp the rules of Internet finance development and spill-over risk, in a bid to ward off disadvantages through comprehensive management. During the initial stage of Internet finance, we should give more support and tolerance in the principle of encouraging financial development and innovation and preventing excessive intervention. In the mid-to-late period, we should put in place early warning and surveillance over the typical risks carried by Internet finance itself and the spill-over risk confronting traditional finance, securing the bottom line from any systematic risks. On the one hand, the regulation of Internet finance industry should be improved as soon as possible, including the rules of access, operation, and exit and the rules of risk identification, early warning, and handling mechanism. At the same time, in order to prevent the vacuum of supervision, the People's Bank of China $(\mathrm{PBoC})$ should clarify the regulatory authority and the regulatory scope on different Internet finance models. On the other hand, the $\mathrm{PBoC}$ should set up a statistical survey system for Internet financial institutions, strengthen the dynamic monitoring of the price, scale, and flow of P2P, crowdfunding, and other network loan, build an effective market firewall, and avoid the "domino effect" caused by risk spillover.

Second, we should adopt differed management strategies tailored to those characteristics of different commercial banks. Also, we need to accelerate the equity restructuring of large commercial banks and cut down monopoly, in an effort to improve efficiency for better embracing the challenges posed by Internet finance; strengthen the risk-management capacity of small-and-medium-sized commercial banks, giving play to such banks to solve capital-raising difficulties of small-and-medium-sized enterprises; and, at the same time, prevent the outbreak of regional financial crisis.

Third, we should steadily proceed with institutional reform of finance, gradually complete the interest rate liberation, and encourage the advantage complementing between Internet and traditional finance, allowing financial sector better serve the real economy so that China's economy could again take off with the booming development of "internet+" industry.

\section{Endnotes}

${ }^{1}$ Source: Monetary Policy Report, The People's Bank of China

${ }^{2}$ According to density possibility scatter-gram of lending scale of commercial banks (this figure was omitted due to the limitation of the paper's size), the lending scale of large commercial banks was mainly seen at the right side of $80 \%$ level. Thus, it was feasible to divide the types of banks based on lending scale.

${ }^{3}$ Normally, Z-value, EDF, risk asset ratio, and asset/equity ratio were adopted for measuring the risk-taking of commercial banks. Given the establishment of model, asset/equity ratio was selected as the proxy index for the risk taking behavior of banks. 
${ }^{4}$ In order to guarantee the consistency of the marks in empirical analysis, in designing the RISK $_{L L}$, the negative ratio between loan-loss reserves and the sum of loans was calculated. Considering that credit risk posed a major risk to commercial banks, the net lending to total assets ratio was seen as the similar figure of RISK $_{L / A}$.

${ }^{5}$ Due to the lack of statistics of total number of annual news in Baidu database, the sum of news covering 10 popular Chinese three- to four-character idioms was considered as the proxy variable for yearly amount of news. The source of data derived from the Report of Language Situation in China is published by the Ministry of Education, P.R. China.

${ }^{6}$ Due to the size of paper, the descriptive analysis of variables was not detailed in the paper. Please contact the author if needed.

${ }^{7}$ What needed to be noticed was that the turning point of models (4) and (6) was 0.7135 and 0.9296 , respectively, 1 year gap between itself and the turning point of benchmark analysis. But it did not affect the $U$-type relation between Internet finance and commercial banks' risk taking. Due to the size of this paper, the regression result following Winsor processing was not listed in detail. Please contact the author if needed.

${ }^{8}$ Due to the size of this paper, the regression result following Winsor processing was not listed in detail. Please contact the author if needed.

\section{Acknowledgements}

This paper is funded by 2015 State Scholarship Fund of China Scholarship Council (project number: 201506280119); National Natural Science Foundation of China "Study on the Risk Recognition and Warning of Real-estate Market Facing Financial Security" (project number: 71373201); and National Social Science Foundation of China "Study on Internet Finance Risk Control and Supervision: Theory, System and Method" (project number: 14AZD033). We greatly appreciate the comments and suggestions given by the editor. The opinions expressed in this paper are those of the authors. All errors remain our responsibility.

\section{Authors' contributions}

PG designed the model framework and model solution, collected the date, performed the empirical analysis, and wrote the article. YS proposed the theoretical basis. All authors read and approved the manuscript.

\section{Authors' information}

Pin GUO is a PHD candidate in the School of Economics and Finance, Xi'an Jiaotong University. She conducts several researches in Internet finance and commercial banks.

Yue Shen is a professor in the School of Economics and Finance, Xi'an Jiaotong University. She conducts several researches in financial liberalization and risks.

\section{Competing interests}

The authors declare that they have no competing interests.

Received: 11 August 2016 Accepted: 25 October 2016

Published online: 10 November 2016

\section{References}

Allen F, Gale D (2000) Financial contagion. J Polit Econ 108(1):1-33

Arellano M, Bond S (2004) Some tests of specification for panel date: Monte Carlo evidence and an application to employment equations. Rev Econ Stud 58(2):277-297

Ariss R (2010) On the implications of market power in banking: evidence from developing countries. J Bank Financ 34(4):765-775

Askitas N, Zimmermann KF (2009) Google econometrics and unemployment forecasting. Appl Econ Q 55(2):107-120 Beltratti A, Stultz RM (2012) The credit crisis around the globe: why did some banks perform better? J Financ Econ 105(1):1-17

Berger AN, Klapper LF, Turk-Ariss R (2009) Bank competition and financial stability. J Financ Serv Res 35(2):99-118 Blundell R, Bond S (1998) Initial conditions and moment restrictions in dynamic panel data models. J Econ 87(1):115-143 Delis MD, Kouretas GP (2011) Interest rates and bank risk-taking. J Bank Financ 35(4):840-855

Guoqiang D, Pengfei F (2014) Supervision innovation, interest rate liberation and Internet finance. Mod Econ Res 7:64-67+82

Haier L, Wuguang S (2015) The focus and conflict in theory of Internet finance. Economist 5:62-67

He D, Wang H (2012) Dual-track interest rates and the conduct of monetary policy in China. China Econ Rev 23(4):928-947

Hellmann TF, Murdock KC, Stiglitz JE (2000) Liberalization, moral hazard in banking, and prudential regulation: are capital requirements enough? Am Econ Rev 90(1):147-165 
Jimenez G, Lopez JA, Saurina J (2013) How does competition affect bank risk taking? J Financ Stab 9(2):185-195 Kishan RP, Opiela TP (2000) Bank size, bank capital, and the bank lending channel. J Money Credit Bank 32(1):121-142 López M, Tenjo F, Zárate H (2011) The risk-taking channel and monetary transmission mechanism in Colombia. Monetary policy, financial stability and the business cycle

Mckinnon Rl (1973) Money and capital in economic development. Brookings Institution Press, Washington Merton RC, Bodie Z (1995) A conceptual framework for analyzing the financial environment. Harvard Business School Press, Cambridge

Mulherin JH, Boone AL (2000) Comparing acquisitions and divestitures. J Corp Finan. 6(6):117-139

Mussa AS (2011) Three essays on financial markets and monetary policy. http://scholarworks.wmich.edu/cgi/ viewcontent.cgi?article $=1443 \&$ context $=$ dissertations

Nautz D, Scheithauer J (2011) Monetary policy implementation and overnight rate persistence. J Int Money Financ 30(7):1375-1386

Nautz D, Schmidt S (2009) Monetary policy implementation and the federal funds rate. J Bank Financ 33(7):1274-1284

Repullo R (2004) Capital requirements, market power, and risk-taking in banking. J Financ Intermed 13(2):156-182

Shahrokhi M (2008) E-finance: status, innovations, resources and future challenges. Manag Financ 34(6):365-398

Shaw SE (1973) Financial deepening in economic development.Oxford University Press, New York

Shujun W, Jiangang P (2014) The studies on the measurement and performance of China's interest rate liberation: empirical analysis based on the bank credit channel. J Financ Econ 11:75-85

Syed AR, Nida H (2013) Factors affecting Internet banking adoption among internal and external customers: a case of Pakistan. J Electron Finance 7(1):82-96

Xiaoqiu W (2015) Internet finance: the logic of growth. Finance Trade Econ 2:5-15

Xun W, Johansson A (2013) Financial repression and structural transformation. Econ J 1:54-67

Yue S, Pin G (2015) Internet finance, technology spillover and commercial banks TFP. J Financ Res 3:160-174

Zhilai Z (2015) The influence of Internet finance of commercial banks-based on the perspective of the influence of "Internet + " on the retail industry. Financ Econ 5:34-43

Zhiwu C (2014) How fresh is the Internet finance. New Finance 4:9-13

Zhixian G, Cheng L, Shengfu L (2015) The coordination between monetary policy and prudential supervision. Mod Econ Sci 1:55-66 + 126

\section{Submit your manuscript to a SpringerOpen ${ }^{\circ}$ journal and benefit from:}

- Convenient online submission

- Rigorous peer review

- Immediate publication on acceptance

- Open access: articles freely available online

- High visibility within the field

Retaining the copyright to your article

Submit your next manuscript at $>$ springeropen.com 